\title{
Nevus lipomatosus superficialis
}

\section{Mancy Abdullah, Ahmed Lateef}

\author{
Al-Ramadi Teaching Hospital, Al-Anbar Health Directorate, Ministry of Health, Iraq
}

Corresponding author: Dr. Mancy Abdullah, E-mail: abdmancy@yahoo.com

Nevus lipomatosus superficialis (NLS) is a rare type of connective-tissue nevus that appears before the age of 20 with an equal sex ratio and that usually manifests itself as soft, yellowish or skin-colored papules or plaques on the buttocks or the trunk, solitary or multiple with varying configurations. An NLS consists of mature adipose tissue within the dermis. No treatment is required [1-3].

A 16-years-old female presented to a dermatology clinic complaining of multiple yellowish papules and plaques confined to the right lower lateral trunk that had been visible since the age of 4 . An examination of the skin revealed multiple soft yellowish papules and plaques of different sizes in a zosteriform distribution located on the lower lateral trunk (Fig. la). An incisional biopsy was taken for histopathological examination and revealed adipose tissue present throughout the dermis (Fig. 1b). The diagnosis of nevus lipomatosus superficialis was confirmed. The patient was referred to a plastic surgery clinic for further treatment.

\section{Consent}

The examination of the patient was conducted according to the principles of the Declaration of Helsinki.

The authors certify that they have obtained all appropriate patient consent forms, in which the patients have given consent for images and other clinical information to be included in the journal. The patients understand that their names and initials will not be

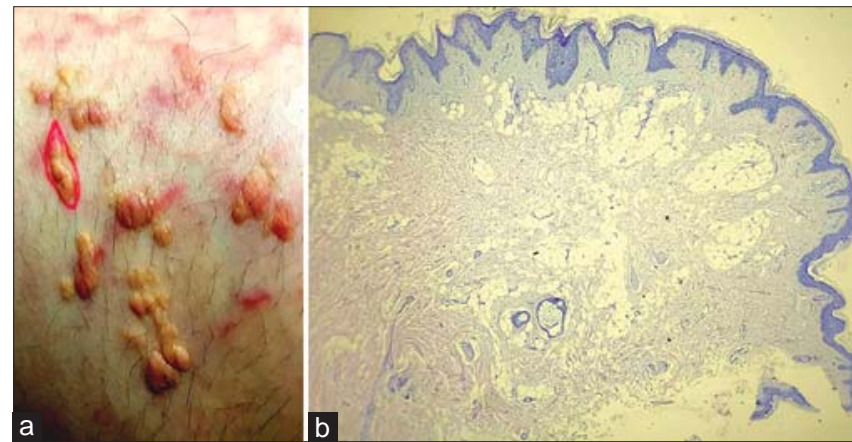

Figures 1: (a) Nevus lipomatosus superficialis. (b) Mature adipose tissue in the dermis $(\mathrm{H} \& \mathrm{E}, \times 10)$.

published and due effort will be made to conceal their identity, but that anonymity cannot be guaranteed.

\section{REFERENCES}

1. James WD, Elston DM, Treat JR, Rosenbach MA, Neuhaus IM. Dermal and subcutaneous tumors in: Andrews" diseases of the skin. Clinical Dermatology.13th ed. Elsevier, 2020,587- 636.

2. Mentzel T, Brenn T. Lipogenic neoplasms. In: Kang S, Amagai M, Bruckner A, Enk A, Margolis DJ, Mcmichael AJ, Orringer JS.(eds). Fitzpatrick's Dermatology, 9th ed. New York: McGraw-Hill, 2019;2172-99.

3. Al Gaadi S, Al Godayan S, Bukhari I. Lipedematous scalp: Case report and review of the literature. Our Dermatol Online. 2016;7:198-200.

Copyright by Mancy Abdullah, et al. This is an open access article distributed under the terms of the Creative Commons Attribution License, which permits unrestricted use, distribution, and reproduction in any medium, provided the original author and source are credited.

Source of Support: Nil, Conflict of Interest: None declared. 